\title{
From dependence to interdependence: Towards a practical theology of disability
}

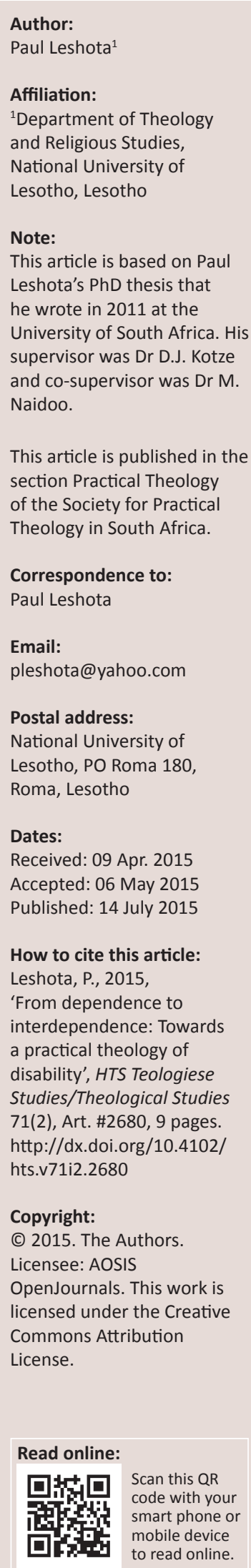

Disability has remained on the fringes of research in Africa in general and Southern Africa in particular, especially in the field of theology. Its glaring absence constitutes an indictment against both church and society, revealing in the process both the church's and society's penchant for a dependence paradigm which has been the paradigm with respect to issues of disabilities and people with disabilities. Using the participatory method with its proclivity for bringing to the fore the voice of the 'other' and the marginalised, both the dependence and independence paradigms within the context of disability are put under scrutiny. In the process and through the voice of people with disabilities, the practical theological paradigm of interdependence emerges as the most appropriate and friendliest one, as it resonates with both the New Testament notion of koinonia through love and the African notion of botho through interconnection. The practical theology of holding each other in arms resonates with the theology of embrace that has been popularised by Volf within the context of much hatred and alienation. All these different dimensions of the theology of interdependence become the bedrock for inclusive and respectful treatment of each other irrespective of race, gender, religion, ability and social class.

\section{Introduction}

The voice of Denise Ackermann (1994, 1998), embodied in her feminist version of practical theology, breathed some fresh air into what had become the male, white, middle-class, clerical and able-bodied dominated field of practical theology within the Southern African context. At the same time, she challenged the lethargy with which the issues of gender disparities, disablism, racism, clericalism and classism were addressed. Although she addressed herself mainly to painful experiences that resulted from the many years of alienation and suppression of the female voice in practical theology, she also had her eye on other sections of society that were previously marginalised and in need of healing (Ackermann 1998:83). One such group are people with disabilities. Disability is a subject that has been, and still is, on the fringes of research in Africa in general and Southern Africa in particular, especially in the field of (practical) theology. The dearth of literature on the subject does not match the seriousness and prevalence of the issue. Anderson and Blair (2003:70), writing from a Western perspective, bemoan the omission of such a prominent issue from theological consideration, despite Jesus's proclivity for it. As such, its glaring absence in theological discourse constitutes exclusion ${ }^{1}$ (Anderson \& Blair 2003:1) and an indictment against the church, which as the body of Christ, the koinonia, is called to serve (diakonia) everyone through love.

The perception that has up to now been created in both church and society about people with disabilities is one in which they are seen as 'misfits', 'sinners', 'abnormal' and objects of pity who have no voice and cannot have a voice because of their alleged condition of inability, impurity and sinfulness. In the process, some have reduced them to dependents who are only able to survive through reliance on others (Oliver 1993:54). In an effort to improve their situation, others have shoved them to another extreme, that of interdependence (Ntlatlapa 2007). In this study these two contrasting paradigms, that of dependence and that of interdependence are interrogated, whether or not they represent the experiences of people with disabilities. With the latter's participation, a friendlier and more fitting paradigm that is reflective of the nature of the church as the body of Christ is proposed and argued for, which is the paradigm of interdependence. Within such a paradigm there cannot be any misfits and abnormal people as all belong together and are members of the same body.

1.The implied notion of inclusion, though pertinent in the discussions around issues of disabilities, will not feature prominently as a stand-alone concept in this article, firstly, because the main ideas raised and followed in this article were those raised by the participants in the research and, secondly, because the idea does not fit well in the dependence, independence and interdependence continuum adopted by the article. However, the notion of church as koinonia and its cognates has an implied nuance of inclusion. Faith in Jesus is the only condition for inclusion into the fellowship that is the church. 


\section{Contextual practical theology of disability}

The reflection done in this article is situated within the context of practical theology. If practical theology is to remain true to its qualification as theology, it has to fuse two horizons: that of the text and that of the person to whom the text speaks (context) (Gadamer 1975:358). Müller (2003:296) concurs that practical theology is only possible as contextual theology, for it operates within local, concrete and specific contexts. I therefore position myself within a practical theology that takes context seriously. The context, in this case, is disability, characterised by marginalisation and ostracisation by both church and society. While I will be addressing disability in general, the concrete and specific experiences of people with disabilities in Lesotho, who are participants in this article, will be given special attention. My contention is that while disability may be a universal phenomenon, it finds its most tangible and concrete expression in the context within which people with disability live. Such a phenomenon is embedded within a specific social and cultural context which is neither global nor universal. The matrix of values, beliefs, life assumptions and language which we call 'culture' shape people's experiences of disability as conceptualised and lived in that context. These experiences, values, beliefs, life assumptions and language taken together provide the lenses, through which the experiences of disability are mediated.

There is no denying, however, that some of the experiences articulated here may resonate with experiences from elsewhere. This article, therefore, goes beyond examination and analysis of ideologies and structures, to working together in the discovery of an alternative pastoral disability paradigm. The oft-missing voice of people living with disabilities in social and theological discourses is recognised and given space to articulate the hurts, concerns and aspirations of people with disabilities from their social and faith perspectives. This restoration of voice has enabled the appropriation of experiences of people with disability in theological discourse, to restore theology to where it belongs, as a reflexive endeavour founded on people's faith experiences that cannot be divorced from their context. The paradigm developed in this research is not only contextually situated, but it also gives voice to the local knowledge systems of people that have hitherto been silenced. Within the context of disability, this means acknowledging the cultural specificity and individual uniqueness of every experience of disability. As Eiesland (1994) notes:

The corporeal is for people with disabilities the most real. Unwilling and unable to take our bodies for granted, we attend to the kinesis of knowledge. That is, we become keenly aware that our physical selves determine our perceptions of the social and physical. These perceptions, like our bodies, are often nonconforming and disclose new categories and models of thinking and being. These new embodied categories arise from the concrete experiences of people with disabilities. (p. 31)

Even as Eiesland writes in terms of 'we', there is always the ' $\mathrm{I}$ ' that is hidden in that 'we'. For although the experience of disability comes to each according to stereotypes and prejudices created in society through interaction, its effect cannot merely be reduced to a simple group feeling. This experience has an impact that will differ from one individual to the other and that should not be taken for granted. This view is articulated by Schutz (quoted in Eiesland 1994:31) as, 'The place which my body occupies within the world, my actual "Here" is the starting point from which I take my bearings in space. It is, so to speak, the centre in my system of coordinates.'

It is my contention that although disability is found in all cultures, its expression and interpretation are determined by the context within which it is experienced. Contextual theology, therefore, with its critique of the universal and its propensity towards the insurrection of the marginalised knowledge systems, would be apt in facilitating healing on both sides of the disability divide, at both social and personal levels. Each participant's voice was listened to from within its own experiential context. Although several common disability concerns were always detected, the unique situation of every individual with disability was acknowledged and taken seriously.

Since the research was carried out in Lesotho, the experiences of participants were shaped within the context of that country. Their foregrounding is demanded, not only by our adoption of a participatory method but also by the theological stance adopted, that is, contextual theology.

\section{Doing practical theology as participation}

Our choice of a participatory method of research actually facilitates the doing of theology from below, as it allows the genuine reflections of people with disabilities to come to the fore. Theology from below is a form of contextual theology that is rooted in human experiences, particularly the experiences of those who have been labelled 'the least, last and the lost' (Rocke \& Van Dyke 2012:17). Its penchant for taking seriously the experiences of such people, as well as drawing from their stories, symbols and reflections, situates it where it belongs. That is, as Rocke and Van Dyke (2012:18) put it, 'at the lowest places where God's grace pools up.' Without people's experiences such a theology would remain a hollow enterprise offering no sustainable benefit to those it seeks to serve.

Theology from below logically leads to participation by those who reflect on their faith experience and who seek to act on its demands. It is, therefore, a theology that takes the voice of the 'other' seriously. The 'other' represent those who, under normal circumstances, 'are disempowered and marginalised; those who seldom benefit from the ethics of discourses created and entertained by the powerful or knowledgeable' (Kotzé 2002:18). Doing theology, no longer the sole preserve of the educated elite, entails engaging in theological reflection that is rooted in real-life experience. Taking a cue from what Bosch (1991:425) calls the 'hermeneutic of the deed', doing 
counts more than knowing: only knowledge achieved through action is capable of transforming the world.

Within the postmodern context, where participation is a defining feature, there is very little room for dealing out theological prescriptions. Instead, immersion in the process of knowledge creation becomes a conditio sine qua non. It is this way of doing theology that is preferred in this article. My engagement, therefore, with people with disabilities and the significant others is a doing theology with. Their experiences of marginalisation, ostracisation, of being denied a voice and of being the last, the least and the lost is teased out and engaged - not without them but with them. This engagement promotes positive and empowering research relationships (Salmon 2007:986), as was later confirmed by the participants. It does not wield a creed with ready-made answers to questions that have not been asked or problems posed by none of those who are participating in this research journey. If it did, it would rightly invite resistance against its shaping of unethical practices (Kotzé 2002:17). But before we engage the concepts of dependence and independence, it would be in order to attempt a definition of disability and perhaps the social and environmental issues that render people with disabilities dependent.

\section{Defining disability in context}

Although it is beyond the scope of this article to give a detailed exposition and evaluation of the various definitions of disability, views around some as well as their evolution are pertinent. Any attempt at standardisation of the definition of disability would be to prioritise fixity over the fluidity of meaning, and thus runs counter to the perspective adopted in this article.

The International Classification of Functioning, Disability and Health (ICF) encapsulates a supposedly inclusive definition of disability adopted by the 191 member countries in defining disability in terms of impairment, activity limitations or restrictive participation (World Health Organization [WHO] 2001:3). Although this definition was intended to be an improved version of an earlier one, it has been adversely criticised, especially by researchers within disability studies. The incorporation of social and economic considerations did not see the definition lose its association with the medical models (Scotch 2002:25.29).

Pfeiffer (2002:4-7) also challenged attempts at defining disability, asserting that 'disability has no scientific or even a commonly agreed upon definition', and rejecting the possibility that it can be identified or measured. The attempts by the World Bank and the WHO (ICF), therefore, can only 'further the agenda of eugenics which eliminate people with disabilities' (Pfeiffer 2002:8). Scotch (2002) echoes the sentiments of Pfeiffer, claiming that disability cannot be defined except with reference to public policy, as 'whatever public laws and programs say it is' (Scotch 2002:24). In a slightly nuanced position, French (1993:17) disputed an either/or definition, and opposed those who describe impairment as a physical problem and disability as a social problem. He opted for a 'both/and' position, suggesting that disability has both physical and social dimensions and, therefore, a comprehensive definition would include both of these dimensions. Grönvik (2007), meanwhile, dedicated his doctoral research to the examination of definitions of disability by different researchers, hypothesising that disability is too complex and contentious to merit a standard definition and that context and purpose determine the content.

Nevertheless, it is useful here to identify four brief definitions of disability as they relate to different models: the first focuses on a person's functional limitations (Grönvik 2007:11); the second on environmental factors to which the individual cannot easily adapt; the third, which is the social model, points to the physical and social environment, not the person himself or herself, as creating barriers to participation in society; the fourth is largely administrative, assessing disability in terms of applicability for aid.

Despite, or perhaps because of these definitions, Grönvik (2007:38) suggests that it is difficult not to conclude that disability is a fascinating, volatile and elusive concept that continues to baffle and puzzle researchers. In dealing with it, efforts should not be expended on finding a universal and 'correct' definition; rather, the focus should be placed on describing how disability has been defined (Grönvik 2007:40). In this way there is room for more subjective definitions that pay attention to individual as well as contextual experiences that have been a missing link in disability studies. Such individual experiences not only form an important component of this article, but also subvert meanings of disability that strive for fixity and universality.

\section{Dependence and disability}

In both society and the church, dependency and disability have for a long time remained synonymous, perhaps more in practice than in principle. The book by Stiker (1999), A history of disability, provides a compendium of the harsh conditions under which people with disabilities lived throughout history, from biblical times to the birth of rehabilitation. Barnes (1997) refers to this condition as a 'legacy of oppression' by Western culture. Throughout this time the constant feature that characterised the life of a person with disability was to be at the beck and call of others, particularly those who allegedly had a claim to normalcy. The latter's call was to determine, declare and dismiss people with disabilities to the doldrums of society. This era has further been associated with what Stiker (1999:105) calls the 'great confinement' or 'massive internment', during which all those who were considered to pose a medical threat to society were placed in secluded places.

The ancient world of Greece and Rome left us a legacy and culture devoid of dignity and respect for people with disability. Their economy was founded on the principle of competitiveness, both intellectually and physically. There was therefore very little room, if any, in such societies 
for people who were considered, by standards of the time, disabled (Barnes 1997). Because of their perceived dependence they were seen as a burden and a reminder of an imperfection which was highly abhorred and dreaded at the time (Dutton 1996:25). This attitude was inherited by the subsequent industrialised, rationalised and medicalised society and church of the 18 th century.

The 19th century marked the upsurge of the exclusion of people with disability from mainstream Western society or what was to be known as the 'Eugenics Movement'. During this time and its aftermath, the common attitude was to view people with physical and intellectual disabilities as posing a threat to Western society (Barnes 1997). In the religious realm Christian charity works, though well meant, perpetuated the dependence of people with disabilities. The church, too, was caught up in the labels and categories constructed and espoused by the larger society on people with disabilities. The centrality of the written and spoken word as well as physical perfection, in many churches, left people with disabilities feeling unwanted and unwelcome (Webb-Mitchell 1996:39).

Although a major shift from the language of dependence is currently taking place in the policies and action plans of countries, the actual practice points to a serious nostalgia for the dependence paradigm. Educational, medical and justice sectors in different countries have displayed propensity for the dependence paradigm, at least in practice. Almost all these sectors place people with disabilities at the mercy of professionals who continue to construct them as institutional subjects whose lives depend on the policies, laws and protocols made by the powerful (Leshota 2011:135). Lesotho is no exception to these attitudes and practices regarding people with disabilities. Despite their presence in every sphere of human life (Anderson 2003:2), the absence, alienation and discrimination that characterise their life experiences are unashamedly glaring. Jack, one of the participants in this study had this to say: 'We have no eyes, ears, voice, mobility and everybody feels entitled to do and say things on our behalf without even asking us.'

\section{Evacuating the dependence and independence paradigms of disability}

The 17th-century 'great confinement', which revolved around segregation aimed at maintaining social order, gave way to a new paradigm with respect to people with disabilities. This was the paradigm of medical power sustained by the ideas of the Enlightenment. Characterised by sharper scientific focus and improved medical treatment of diseases, it marked the emergence of new power which continues to dominate to the present day (Stiker 1999:104). It was during this time that people with disabilities became dependent on the authority of the medical practitioner who only could decide on their needs and desires (Dejong 1979). Persons with disabilities could not continue to rely on others as this degraded their value as human beings and was unsustainable in the long term.
The heroic act of Ed Roberts in the early 1950s set in motion what was to become a landmark project, that of Independent Living (White et al. 2010:235). Developed, run and controlled by persons with disabilities themselves, 'Centres for Independent Living' represented both a desire for selfdetermination and resistance to long-term abuse at the hands of non-disabled people. Central to the Independent Living Movement is maximization of 'leadership, empowerment, independence, and productivity of individuals with disabilities' (White et al. 2010:235).

There is no doubt that the Independent Living Movement made strides not only in subverting the slanted assumptions of the medical paradigm, but also in helping people with disabilities to adopt a lifestyle amenable to their needs (Barnes 2004:7). It has, however, not been able to shed its association with neo-liberal jargon such as self-determination, autonomy, privacy and freedom. Independence, autonomy and freedom all have an implied 'from'. These concepts continue to occupy a central place in neo-liberal culture and discourse which holds its firm grip on politics and policy on a global scale. The Two-Thirds World countries have gotten used to the term independence, particularly in its political sense, but they have not given thought to what it meant and what it means in concrete terms. Dube (2000) opines thus on this matter:

The postindependence experience of many Two-Thirds World countries has also rudely shown that 'independence' from other nations and cultures, even from those that oppressed them, is neither practical nor the best means for survival. (p. 185)

The point which Dube ably demonstrates is that within the economy of human interaction the concept of independence is impracticable, as humans cannot afford to untangle themselves from other humans. Its application is even more difficult in contexts where interconnectedness, kinship and relationality are the defining features of what it means to be human (Mbiti 1969:91-92; Ogbonnaya 1994:10; Tutu 1999:35). Africa in general and Lesotho in particular, despite long years of colonial and neo-colonial onslaught, still show proclivity for their culture and worldview, particularly the ubuntu aspect with its feature of interdependence.

\section{Embracing the interdependent paradigm in disability issues}

There is an acknowledged shift of paradigms from being dependent on others, to being independent from them and to being interdependent with them, particularly within the context of disability. The following conversation with Jack, one of the participants in this research article, reflects this shift:

Paul: 'Could we say, as people with disabilities, that we are dependent on others for our survival?'

Jack: 'That assertion suggests a one-way street, that is, we [people with disabilities] depend on others and not vice versa.'

Paul: 'Could we then say we are independent from them?'

Jack: 'That would be another extreme ... Eh ... I think it is becoming clear that we need each other and so we better call ourselves interdependent.' 
Paul: 'So you mean non-disabled people depend on you in some instances!'

Jack: 'Absolutely. Yes they do. When there is no light in the house my wife and my children, for example, rely on me to navigate the room. You also see that the whole University staff relies on Reg's memory to connect them to people they want to talk to through phone without having to make them wait as he flips through the telephone directly. Can you imagine how much time, perhaps money as well, are saved in not having to flip through the telephone directory with every call that goes out? Clearly you need us in some instances and we need you sometimes to navigate these ungodly surrounding with steps and holes all over. So I think we do not entirely depend on you and you do not entirely depend on us. It is not correct to say you are entirely independent from us. And to want to live independently from each other would be a travesty of our sociability as humans. But we should not forget that we also interdependently, depend on God.'

Interdependence derives from people's nature as social beings. This is even more pronounced in the African worldview where the self is inconceivable outside the community. Mbiti (1969) and Ogbonnaya (1994) are among several African scholars who have spared no effort in underscoring the significance of the notion of communalism and its attendant attributes of interconnectedness and interdependence in an African worldview. In their view, communality is foundational to the African worldview (Mbiti 1969:91-92), and interdependence is the basis of relations within the community (Ogbonnaya 1994:10). The reality of interdependence is further confirmed in the Bible.

Below we discuss in a more expanded way the practical theologies with resonance from the already existing theological nomenclature that emerged out of our conversations with people with disabilities.

\section{Practical theology of 'botho' ('ubuntu')}

In conversation, Jack said, 'We all need to display "botho" in order to live peacefully and harmoniously with everybody for as we say "motho ke motho ka batho"', evoking what has come to be known as authentic Africanness embodied in a much celebrated notion of botho or ubuntu. 'Botho' is a Sesotho word that captures the essence of what it means to be human (Murithi 2009:226). The concept is found in many forms in a number of societies throughout Africa, in almost all of which it represents personhood or humaneness (LenkaBula 2008:378).

Botho touches on all aspects of life because in the African worldview everything is interconnected, without compartments. The personal, political, economic, psychological, religious and relational are all intertwined, while personhood is defined relationally (Mkhize 2004:4-24). Although the adage of motho ke motho ka batho is often cited in the discussions around African notions of personhood, Mkhize (2004:5-24) believes that its dialogical implications have not been fully appreciated: 'selfhood within the context of Africa emerges dialogically, through participation in a community of other human beings' (my emphasis).

As seen by Tutu (1999), botho is a way of being in the world and finds its truest expression in different facets of people's lives. It is in this context that the rites of passage can be called components of the liturgy of life in Africa. Their celebration and the rituals associated with them always have a communal component of the ' $\mathrm{we}^{\prime}$ as opposed to the ' $\mathrm{I}$ '. Their social function is rooted not only in their involvement of the living but also in the involvement of the living dead, the ancestors and the spirits (Bourdillon 1990:18-48). Because people (batho) are called and ordered towards unity, rituals and rites of passage function to cement that unity and communion (Bourdillon 1990:24). Botho, therefore, recognises that no person can exist in isolation and that as interdependent beings people exist in a complex network of relationships. In a botho worldview, solidarity is key (LenkaBula 2008:381), so an injury to one member is bound to affect the entire web of relationships, whether suprahuman, human or ecological. This view is further buttressed by the strong tendency towards unity that is found in the Sesotho ${ }^{2}$ proverbs. The proverbs are not only reflective of the wisdom of society, but are also yearnings for what the society should continue to be (Mokitimi 1997:23).

Gade (2012) in his interesting article, 'What is Ubuntu?', discovers two different clusters among South Africans of African descent, namely, those who view ubuntu as (1) moral quality of a person or (2) a philosophy or worldview according to which persons are interconnected (my emphasis). I do not think we have to pit one against the other as both can coexist. Botho, as it were, is a way of being which expresses itself in concrete actions and personal casts of generosity, hospitality, friendliness, caring and compassion which all point to a virtuous life. Botho is further seen and anchored in an African life (Bhengu 1996:10). Life is what we live, in word and deed. This life of word and deed is not only grounded in communion and relationships, but it is also an expression and manifestation of that communion; hence, the practical theology of botho.

\section{Practical theology of koinonia}

Jack's words above, that we interdependently depend on God, brought a Christian theological touch, evoking, as it were, a link with a theology of communion, expressed and captured aptly, through different metaphors, in the New Testament writings. In fact this idea of church as koinonia stood out in conversations with Reg, another participant, who when quizzed on the meaning of church as people of God spoke of the nuance of fellowship, communion, belonging, sharing and participation. Gleeson (2006:2) states that the church in its origin, nature and mission is held together in a fundamental

2 Sesotho is a word used to refer to the way of life of the Basotho people Several of their proverbs emphasise unity and working together Proverbs are appreciated not their proverbs emphasise unity and working together. Proverbs are appreciated no only for their linguistic and aesthetic value, they are also valued for their importance in shaping how people should see the world, how they should relate with others and how they should feel the atmosphere in the society in which they live. 
unity and communion of faith and life which is made up in and by Jesus Christ. The metaphors of a building with Jesus as the foundation stone, a vine with Jesus as the stem, a flock with Jesus as the shepherd, a body with Jesus as head, point to a life of communion and unity all held together by attachment to Jesus (Gleeson 2006:2). These metaphors find a new expression in John and in the Acts of the Apostles which is that of koinonia, especially as articulated in Acts (2:4-14), John (15:1-17) and in 1 Corinthians 12.

In the above contexts the central idea is that of sharing, participation and impartation deriving from unity and communion of life. Communion of the Father, Son and Holy Spirit are foundational to the communion between and within members of the church. The bonding attributes and manifestations of this unity and communion are love, compassion, tolerance, care, understanding, mutual responsibility and concern for others' welfare. Communion or koinonia is not some kind of Orwellian Sugar-Candy Mountain expressed only in lofty words with no corresponding concretisation of those ideals. It is held together by a bond of love which derives its strength from the Trinitarian intimacy (Navone 1989:26).

Relationship with God and with one another is a defining feature of a church as communion or koinonia. This relationship derives from the Trinitarian relationship and it should be seen as a participation in that eternal conversation of the Trinity (Navone 1989:25). Humans are, as Navone (1989:24) suggests, 'communitarian by nature, conceived and born in and through human community. We are interdependent.' In communion, and where participation and sharing are features, differences are not assimilated but appreciated and celebrated.

\section{Practical theology of embrace: Embracing each other}

Jack and Reg expressed a common sentiment regarding making the world more humane: Re lokela ho ts'oaranang $\mathrm{ka}$ matsoho, translated as 'We need to hold each other in arms', although in Sesotho it is more than this and carries the nuance of equality: accepting each other with one's strength or contribution. I have found the metaphor of embrace or what Volf $(1992,1995,1996,2002,2004)$ calls a 'catholic personality', more akin to what ts'oaranang ka matsoho stands for. Such an embrace comes out clearly within the context of the botho worldview and koinonia.

Although the metaphor of embrace has been explored by a number of scholars from a wide range of disciplines, it was Volf (1996) who offered a comprehensive theological exploration of the metaphor, exploiting this metaphor to confront the reality of exclusion which has reigned unfettered throughout the history of the church. ${ }^{3}$ The object of exclusion at best and hatred at worst has been

3.We need to acknowledge, though, that the framework within which Volf developed his ideas has 'identity' as its starting point, 'others' as its catalyst and 'reconciliation' as its end result. the 'other' and the 'different', which incidentally became part of Volf's experience in Croatia. His metaphor of embrace revolved around four structural elements, namely, opening arms, waiting for response, closing arms and opening arms again. They are adopted here with some ideas from De Saint Exupéry's work titled The little prince; hence, starting with closed arms:

\section{Closed arms}

According to De Saint Exupéry (1943:58), closed arms would be the best place from which to begin. The embrace of Volf would resemble the taming of De Saint Exupéry, and to tame is to establish ties. To establish ties derives from the need for each other, but it is not automatic. It takes patience, sitting down a little distance and looking at one from the corner of the eye, saying nothing. This would be the guarded closed arms and the patient looking at each other. It would invite the meeting of hearts and an unpresumptuous trust that is necessary for embrace to take place - an embrace that expresses itself through caring with as opposed to caring for.

\section{Opening arms}

Opening the arms is a bodily gesture of reaching out to another. It underlines the inadequacy of the self and its need for the 'other' for its relational survival. It further signals a creation of a space in oneself for the other (Volf 1996:141). The gesture says that 'others are seen as potentially enriching friends' (Volf 2002:16). It is within the context of what Wolgemuth and Donohue (2006:1033) call an ethic of friendship that one's own vulnerabilities and weaknesses create space for a deeper and more articulated understanding of care. Opened arms represent the comfort that creates space for ambiguity and transformation (Wolgemuth \& Donohue 2006:1033). This ambiguity conspires with the kenotic selfweakening to open possibilities for the discovery of the silenced and marginalised other. This is an exercise in selfemptying without which the Trinitarian love cannot be fully experienced. While self-emptying may sound good enough, it has, however, been a source of pain for people who became too trusting and went into the caring for which masqueraded as caring with. The opening of arms is an invitation for the other to participate in the creation of fellowship (koinonia). Fellowship implies admission of the need to be enriched by others as well as one's potential to be enriched by the other. The opening of arms, therefore, signifies the need to love as well as the need to be loved. It is openness for mutual enrichment.

\section{Waiting for response}

This phase points to the reciprocal nature of the movement of embrace. The waiting arms are actions of allowing the 'other' to have the power to respond or not to respond to the invitation (Jacobs 2004:258). It is a reminder that there is no coercion involved in embrace, and reciprocity is at the core of this movement. It loathes manipulation, violence and coercion, and, as Volf (1996:142) argues, the power of the 
waiting self is the power of the self, which does not break the boundaries and force itself into the other but rather operates through respect, gentleness and hope to achieve what one would call a reciprocal dance of embrace. This waiting allows for the other to say, 'I am ready, and now I can trust enough to flung myself into the arms of the other.'

\section{Closing arms}

This marks the end for which the opening of arms was carried out. It is realised in the active holding of the other and the passivity of being held by the other (Volf 1996:143). It points to the occupation of the space created by both parties on both sides of the embrace continuum. Elsewhere Volf (1995) describes it thus:

Closed arms are a sign that I want the other to become a part of me while I at the same time maintain my own identity. By becoming part of me, the other enriches me. In a mutual embrace, none remains the same because each enriches the other, yet both remain true to their genuine selves. (p. 203)

For the closing of arms to be accomplished without the other being crushed or annihilated requires gentleness and respect. Both respect and appreciate the other's need to maintain that otherness and difference, because it leads to possibilities of transformation for both parties to grow in ways that would not have been imagined before. This is what Volf (1995:199) calls a 'catholic personality', and points to susceptibility to enrichment by otherness and difference. It is a personality that becomes what it is because 'multiple others have been reflected in it in a particular way'. This is the holding each other in arms (re ts'oaraneng ka matsoho) implied by Reg. In the closing of arms, space for the other and the different is created within one's own sense of identity. One's identity and the other's identity, in the process of making space for the other, are both reconfigured (Volf 1996:91).

\section{Opening arms again}

This an invitation for the other to return, a gesture that acknowledges that embrace was not total identification with the other but a relationship which allows for both becoming part of another while at the same time maintaining their own otherness. Opening arms is letting the other go, so that boundary-making does not preclude the embrace of yet others (Volf 1996:145).

Within the context of disability, the metaphor of embrace underlines the importance of regard for oneself which is linked to regard for the other. Even though dehumanisation of people with disabilities has fed on their 'otherness' (Weingarten 2003:160), without that otherness there is no reason to reach out or to love. According to Levinas (1984:166), love consists of the acceptance of the difference of the other. According to the Bible, this is the love of Christ to humanity who, despite his innocence, loved unrepentant humanity with the love that surpasses all knowledge (Lk 15:11-32; Eph 3:19). Through his death and resurrection God became accessible, healed believers, developed relationships and made possible inclusiveness as hospitality (Stookey 2003:95-100). Through his cross, he made it possible to go beyond the exclusion versus inclusion binary to a deeper reflection on interdependence (Newell 2007:326).

\section{Theology of interdependence: When we need each other}

The theology of interdependence as visualised by participants in this research is founded on the two pillars of koinonia and botho, which are further marked out and held together by a feature of embrace (see Figure 1). Although they derive from and represent two different worldviews, a natural synergy between Christian spirituality (koinonia) and botho cannot be missed. The Christian notion of koinonia expresses itself in the values of communion, belonging, sharing and participation which are founded on what Falcao (1988) would call 'Trinitarian co-operation'. The Trinitarian intimate relationship is paradigmatic of how Christians should behave towards each other (Ac 2-4). In a way, the Trinity has both vertical and horizontal dimensions.

Within the Lucan worldview, Christians did not regard what they had as belonging to the individual, as all was common property, stemming from a sense of mutual belonging and mutual need for each other. Read in the light of Pauline metaphor of the body, this meant that the starving of one member was tantamount to starving of self and, consequently, the starving of the group. This sense of fellowship suggests that all who have faith in Jesus belong and have the right of participation.

The notion of botho, too, implies communalism, interconnectedness, relationality and participation which cannot be fully appreciated outside its religious context. Anyone who lives according to the ancestral dictates can hardly fail to manifest the above values, embodied in botho, as the life of the ancestors is prolonged in the life of the living (Pula 1990:13). It, therefore, has both vertical and horizontal dimensions. This sense of mutual belonging within the botho worldview is expressed in concrete actions of generosity, hospitality, friendliness and compassion to others (Mkhize 2004:4-24). The underlying proposition for both koinonia and botho is that we belong together and we are inextricably bound. It is in this sense that Tutu speaks of a natural synergy between the Christian values and ubuntu. Ultimately both of them originate from God through the mind of God's creation.

It, therefore, goes without saying that we share in the same humanity with people with disabilities. We are through them and they are through us. We share with them in the same botho and are members of the same body through faith in Jesus. We are better seen as interdependent. However, that interdependence does not take away the fact that we are distinct identities and to be different is divinely ordained as we are such because God willed it to be. Being different does not necessarily imply competitiveness, hostility and exclusion. Given our vulnerability and our 


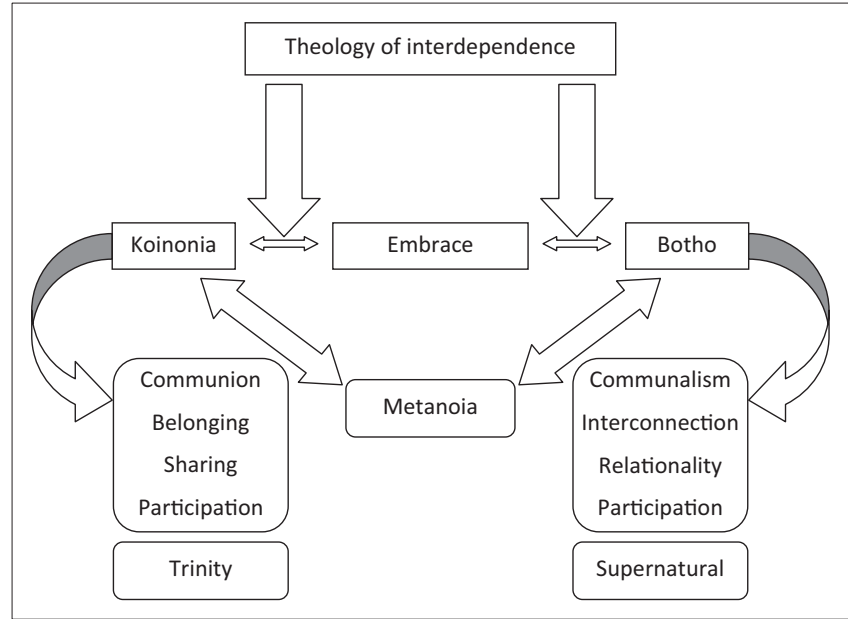

FIGURE 1: Theology of interdependence as visualised by participants.

proneness to dehumanisation, we need to submit ourselves to the process of metanoia and constant change of heart. Metanoia, read in the light of botho and koinonia consists in the undoing of and turning away from attitudes that seek to relate to other humans in ways that are exploitative and dehumanising (LenkaBula 2008:387). Within the context of the theology of interdependence, founded on botho and koinonia, dehumanisation of the other, though real, is untenable. As Tutu (1999:35) observes, 'in the process of dehumanising another, the perpetrators are inexorably being dehumanised as well'. Indeed we cannot afford to keep on dehumanising ourselves in others for that is theoretically and practically unsustainable. Botho is a local representation of koinonia - with differing emphases underpinning the need for people to engage in what Ogbonnaya (1994:77) calls a 'dance of harmony'.

Kwon (2001:43) too, views interdependence through a matrix of relational self (communion). Kwon's point is buttressed by an Interim Statement by the World Council of Churches, $A$ Church of All and for All (2003), which defines the church as 'a place and process of communion ... a place of hospitality and welcome'. It is essentially viewed as a true community of people founded and nurtured by God who, though different, complement each other in their gifts and talents (WCC 2003:\#85). One can therefore talk about the theology of interdependence, with people not interdependent simply because some have disabilities, but because they are by nature inadequate and insufficient. They are, as the Interim Statement asserts, incomplete without talents and gifts of other people (WCC 2003:\#87).

All people belong to the same human race, to the same creation of God and are created in God's image. Believers are all members of the body of Christ and should have equal share and participation in the life of the church, each according to his or her call and unique gifts. We are neither fully independent nor entirely dependent on others, but are better seen as interdependent. In a community where interdependence is a defining feature our differences do not constitute a reason for exclusion but a reason for the need of others. In a community where interdependence is a defining feature even the so-called non-disabled people begin to realise that people with disabilities are better able than them on certain issues and vice versa hence their need for each other. Figure 1 summarises the foundational tenets of the theology of interdependence and their attributes.

\section{Conclusion}

The paradigm of interdependence, founded on botho and koinonia, finds support from ideas that emerged out of our interaction with people with disabilities. It, therefore, represents the local voice, the voice from below and is, therefore, a theology from below, whose main interlocutor are the marginalised other (Bosch 1991:423). In our case, the 'marginalised other' are people with disabilities whose destinies and fates have been at the beck and call of others. The notion of $u b u n t u / b o t h o$ out of which emerges the practical theology of ubuntu/botho and that of koinonia which share a common feature of embrace, evolved out of our discussion with participants in this research article. There is no intention to suggest that the ideas of botho/ubuntu, koinonia or embrace originate with people with disabilities. What this article is suggesting is that when given voice, people with disabilities are able to articulate their thoughts which have to be used to develop theologies that are amenable to their own experiences. Some of these voices resonate with notions that are well established and in circulation within the fields of philosophy, politics, social sciences and theology.

Welcoming and accepting people with disabilities in the church, therefore, is not only demanded by human nature, it is also conditio sine qua non for the church's existence. If a church is by definition a communion, then mutual dependence, and therefore interdependence, is its defining feature. The notion of dependence that is presumed in the medical model of disability is transcended and rendered untenable by the interdependent nature of the communionbound church. On the other hand, the model of independent living that has been publicised by certain schools of thoughts within disability studies (Ntlatlapa 2007) would run counter to the ideas of a theology of interdependence. Within the context of the theology of interdependence the sustainability of 'independence' as a disability paradigm would be dubious. The theology of botho with its feature of interconnectedness, expressed through acts of hospitality and love, becomes the local expression of the theology of koinonia. They both provide innovative lenses through which people with disabilities should beallowed to occupy their rightful places within human society and within the church. Theology of interdependence, with botho and koinonia as their pillars and embrace as their common denominator, should be allowed to shape attitudes towards disability and people with disabilities.

\section{Acknowledgements}

I would like to thank the participants, in particular people with disabilities, who willingly agreed to participate in this study and who freely shared their experiences and thus made their voices heard. 


\section{Competing interests}

The author declares that he has no financial or personal relationships which may have inappropriately influenced him in writing this article.

\section{References}

Ackermann, D.M., 1994, 'Faith and feminism: Women doing theology', in J.W. De Gruchy \& C. Villa-Vicencio (eds.), Doing theology in context: South African perspectives, pp. 197-211, Orbis Books, Maryknoll, NY.

Ackermann, D.M., 1998, “'A voice was heard in Ramah": A feminist theology of praxis for healing in South Africa', in D.J. Ackermann \& R. Bons-Storm, Liberating faith practices: Feminist practical theologies in context, pp. 75-102, Peeters, Leuven.

Anderson, D.W., 2003, 'Special education as reconciliation', Journal of Education and Christian Belief 7(1), 23-25. http://dx.doi.org/10.1177/205699710300700104

Anderson, R.C. \& Blair, W.D., 2003, Survey of theological education and people with disabilities, The Centre for Religion \& Disability, Inc., Birmingham, AL.

Barnes, C., 1997, 'A legacy of oppression: A history of disability in Western culture', in C. Barnes \& M. Oliver, Disability studies: Past, present and future, pp. 3-25, The Disability Press, Leeds.

Barnes, C., 2004, Independent living, politics and implications, Centre for Disability Studies, Leeds.

Bhengu, M.J., 1996, Ubuntu: The essence of democracy, Novalis Press, Cape Town.

Bosch, D.J., 1991, Transforming mission. Paradigm shifts in theology of mission, Orbis, New York, NY.

Bourdillon, M., 1990, Religion and society: A text for Africa, Mambo Press, Gweru.

Dejong, G., 1979, 'Independent living: from social movement to analytic paradigm', Archives of Physical Medicine Rehabilitation 60, 435-446.

De Saint Exupéry, A., 1943, The little prince, Houghton Mifflin Harcourt, New York, NY.

Dube, M., 2000, Postcolonial feminist interpretation of the Bible, Chalice Press, St. Louis, MO.

Dutton, K., 1996, The perfectable body, Cassell, London.

Eiesland, N.L., 1994, The disabled God: Towards a liberatory theology of disability, Abingdon, Nashville, TN.

Falcao, N., 1988, Theology of co-operation: Christ the liberator and man the cooperator, Urbaniana University Press, Rome.

French, S., 1993, 'Disability impairment or something in between', in J. Swain, V. Finkelstein, S. French \& M. Oliver (eds.), Disabling barriers - Enabling environments, pp. 17-25, Sage, London.

Gadamer, H., 1975, Truth and method, Crossroads, New York, NY.

Gade, C.B.N., 2012, 'What is Ubuntu? Different interpretations among South Africans of African descent', South African Journal of Philosophy 31(3), 484-503. http:// dx.doi.org/10.1080/02580136.2012.10751789

Gleeson, B., 2006, 'Images and understandings of the church in the New Testament: An overview', Australian Journal of Theology 8, 1-12.

Grönvik, L., 2007, Definitions of disability in social sciences: Methodological perspectives, Acta Universitatis Upsaliensis, Uppsala.

Jacobs, A.I., 2004, 'Disabled identities: Pastoral work with people who are mobility impaired', DTh thesis, Department of Practical Theology, University of South Africa.

Kotzé, D., 2002, 'Doing participatory ethics', in D. Kotzé, J. Myburg, J. Roux \& Associates (eds.), Ethical ways of being, pp. 1-34, Ethics Alive, Pretoria.

Kwon, S., 2001, 'Codependence and interdependence: Cross-cultural reappraisal of boundaries and relationality', Pastoral Psychology 50(1), 39-52. http://dx.doi. org/10.1023/A:1010495016418

LenkaBula, L., 2008, 'Beyond anthropocentricity: Botho/Ubuntu and the quest for economic and ecological justice in Africa', Religion and Theology 15(3/4), 375-394.

Leshota, P.L., 2011, 'A deconstruction of disability discourse amongst Christians in Lesotho', DTh thesis, Department of Practical Theology, University of South Africa.

Levinas, E., 1984, 'Peace and proximity', in A.T. Paperzak, S. Critchley \& S. Bernasconi, Levinas basic philosophical writings, pp. 161-170, Indiana University Press, Bloomington, IN.

Mbiti, J., 1969, African religions and philosophy, Heinemann, London.
Mkhize, N., 2004, 'Sociocultural approaches to psychology: Dialogism and African conceptions of the self', in D. Hook, N. Mkhize, P. Kiguwa \& A. Collins (eds.), Critical psychology, pp. 53-83, UCT Press, Cape Town.

Mokitimi, M.I., 1997, The voice of the people, Unisa Press, Pretoria.

Müller, J., 2003, 'HIV/AIDS, narrative practical theology, and postfoundationalism: The emergence of a new story', HTS Teologiese Studies/Theological Studies 60(1/2), 293-306. http://dx.doi.org/10.4102/hts.v69i2.1299

Murithi, T., 2009, 'An African perspective on peace education: Ubuntu lessons in reconciliation', International Review of Education 55(2/3), 221-233. http://dx.doi. org/10.1007/s11159-009-9129-0

Navone, J., 1989, Self-giving and sharing: The Trinity and human fulfillment, Liturgical Press, Collegeville, MN.

Newell, C., 2007, 'Disabled theologies and the journeys of liberation to where our names appear', Feminist Theology 15, 322-345. http://dx.doi. where our names appear', Fem
org/10.1177/0966735006076170

Ntlatlapa, M., 2007, 'Lesotho-traditional \& socio-political disability paradigms', in Rolling Rains Report: Precipitating Dialogue on Travel, Disability, and Universal Design, viewed 12 September 2010, from http://www.rollingrains.co./2007/11/

Ogbonnaya, A.O., 1994, 'Person as community: An African understanding of the person as an intrapsychic community', Journal of Black Psychology 20, 75-87. http://dx.doi.org/10.1177/00957984940201007

Oliver, M., 1993, 'What's so wonderful about walking?', inaugural professorial lecture, University of Greenwich, London.

Pfeiffer, D., 2002, 'The philosophical foundations of disability studies', Disability Studies Quarterly 22(2), 3-23.

Pula, A.L., 1990, Jesu Tseleng ea Balimo: Bolumeli ba ho phela thabong ea Molimo, Mazenod Printing Works, Mazenod.

Rocke, K. \& Van Dyke, J., 2012, Geography of grace: Doing theology from below, Street Psalms Press, Washington, DC.

Salmon, A., 2007, 'Walking the talk: How participatory interview methods can democratize research', Qualitative Health Research 17(7), 982-993. http://dx.doi. org/10.1177/1049732307305250

Scotch, R.K., 2002, 'Paradigms of American social research on disability: What's new?' Disability Studies Quarterly 22(2), 23-24.

Stiker, H., 1999, A history of disability, University of Michigan Press, Ann Arbor, MI.

Stookey, L.H., 2003, 'Inclusiveness as hospitality in worship settings', Journal of Religion, Disability \& Health 7(3), 95-102. http://dx.doi.org/10.1300/J095v07n03_08

Tutu, D., 1999, No future without forgiveness, Rider, Johannesburg.

Volf, M., 1992, "Catholicity of "two or three": A Free Church reflection on the catholicity of the local church', The Jurist 52, 525-546. http://dx.doi. org/10.1111/j.1758-6623.1995.tb03698.x

Volf, M., 1995, 'A vision of embrace: Theological perspectives on cultural identity and conflict', The Ecumenical Review 48(2), 195-205.

Volf, M., 1996, Exclusion and embrace: A theological exploration of identity, otherness, and reconciliation, Abingdon, Nashville, TN.

Volf, M., 2002, 'To embrace the enemy: Is reconciliation possible?', in D.B. Kraybill \& L.G. Peachey (eds.), Where was God on Sept. 11, pp. 85-90, Herald Press, Scottdale, PA.

Volf, M., 2004, After our likeness: The church as the image of the Trinity, Eerdmans, Grand Rapids, MI.

Webb-Mitchell, B., 1996, Dancing with disabilities: Opening the church to all God's children, United Church Press, Cleveland, O.H.

Weingarten, K., 2003, Common shock: Witnessing violence every day - How we are harmed, how we can heal, Dutton, New York, NY.

White, G., Simpson, J.L., Gonda, C., Ravesloot, C. \& Coble, Z., 2010, 'Moving from independence to interdependence: A conceptual model for better understanding community participation of centres for independent living understanding community participation of centres for independent living
consumers', Journal of Disability Policy Studies 20(4), 233-240. http://dx.doi. consumers', Journal of Disability
org/10.1177/1044207309350561

Wolgemuth, J.R. \& Donohue, R., 2006, 'Toward an inquiry of discomfort: Guiding transformation in "emancipatory" narrative research', Qualitative Inquiry 12(5), transformation in "emancipatory" narrative research', Qualita
1022-1039. http://dx.doi.org/10.1177/1077800406288629

World Council of Churches, 2003, A church of all and for all - An interim statement, viewed 12 May 2010, from https://www.oikoumene.org/en/resources/ documents/commissions/

World Health Organisation [WHO], 2001, International classification of impairments, disabilities, and handicaps, WHO, Geneva. 